\title{
Estimation of chemical composition, net energy and protein value of lucerne by NIRS and by regression equation based of the days of vegetation or the accumulated temperature
}

\author{
Stefka Atanassova, D. Pavlov and N. Todorov \\ University of Zootechnics and Veterinary Medicine \\ 6000 Stara Zagora, Bukgaria
}

(Received 12 July 1994; accepted 14 September 1994)

\begin{abstract}
The chemical composition, net energy values and protein digestible in small intestine of lucerne primary growth and regrowth samples were estimated by near infrared spectroscopy (NIRS) and by regression equations based on the days or accumulated temperature from the beginning of vegetation.

Regression equations, predicting tested parameters for primary growth samples for one year, were obtained using the days of vegetation (DV) or the accumulated temperature (AT) as independent variables and tested with primary growth samples from the two other years. The prediction accuracy for these parameters by the established equations with both independent factors (DV or AT) was similar and enough for practical purposes.

The NIRS calibration equations for the primary growth or the regrowth showed better or very close accuracy to that of the regression equations with AT or DV. The accuracy of prediction did not differ significantly for both growths. No significant differences in the standard error of prediction were found for samples of the primary growth and regrowth when they were analyzed by a general calibration equation including both growths.

NIRS has an advantage since it is not necessary to observe the DV and $\Lambda T$ and it is possible to analyze samples from different growths with general calibration.
\end{abstract}

KEY WORDS: lucerne, nutritive value, days of vegetation, accumulated temperature, regression equations, NJRS

\section{INTRODUCTION}

The criterion for evaluation of the quality of lucerne forages is their potential to support animal production. Because of the great variation in forages' 
composition and nutritive value during the vegetation period, rapid assessment of their quality is necessary, which will add to the accuracy of prediction of animal performance.

Estimation of nutritive value of the forages on the basis of in vivo digestibility is very expensive and that limits its use for routine evaluation of forages. Laboratory methods which predict the feeding value on the basis of chemical composition and in vitro digestibility are easier, but still expensive and time-consuming.

Another method for estimation of forage quality is based on the use of regression equations. Different equations based on the days of vegetation or morphological stages of development are usually used for determining the content of some nutrients in different lucerne organs or products (Kalu and Fick, 1983; Naidenov, 1988; Minson, 1990).

Near Infrared Reflectance Spectroscopy is widely used as a quantitative technique for analysis of various, forages (Shenk et al., 1979; Marten et al., 1984; Brown et al., 1990). Introduction of NIRS for prediction of chemical composition, the energy value and protein value of forages led to substantial reduction of cost, time and labour.

The aim of the present investigation is to compare two methods for estimation of the chemical composition and the nutritive value of lucerne - NIRS and regression equations on the basis of the days or accumulated temperature from the beginning of the vegetation.

\section{MATERIAL AND METHODS}

During the 3-year period 31 samples from primary growth and 30 regrowth samples of lucerne were collected, beginning at the early vegetation up to full bloom stage. For all samples the chemical composition by Weende method (AOAC, 1980) and the digestibility of nutrients in vivo by classic experiment with wethers, with 10-20 days preliminary and 10 days collection period, following description by Krasteva et al., 1983, were determined. Experimental wethers were fed at nearly maintenance level of energy.

On the basis of chemical composition and digestibility data, feed units for milk (FUM) and feed units for growth (FUG) according to the Bulgarian new energy system (Todorov, 1992), feed units for milk (UFL) according to the French energy system (INRA, 1978) and feed units for milk (VEM) according to the Dutch energy system (Van Es, 1978) were calculated. Protein digestible in small intestine (PDI), according to the French system (Jarrige, 1989), was determined using experimental data for protein degradability in sacco by method of Mehrez 
and Ørskov (1977). Effective degradability was calculated according to the model of McDonald (1981) at 0.06 delution rate of rumen content.

The different regression equations for predicting crude protein (CP), crude fibre (CF), net energy and protein value were obtained using the days of vegetation (DV) or the accumulated temperature (AT) as independent variables. The days of vegetation were counted beginning with the day with stable average day temperature higher than $5^{\circ} \mathrm{C}$. The accumulated temperature was calculated as a sum of positive temperature from the beginning of vegetation (Rubin, 1976). In order to describe forage nutritive value $(\mathrm{Y})$ as a function of DV or AT - (x) the following equations were tested:

$\mathrm{Y}=\mathrm{a}+\mathrm{b} \cdot \mathrm{x}, 1 / \mathrm{Y}=\mathrm{a}+\mathrm{b} \cdot \mathrm{x}, \mathrm{Y}=\mathrm{a}+\mathrm{b} \cdot \mathrm{x}+\mathrm{c} \cdot \mathrm{x}^{2}$, and $\mathrm{Y}=\mathrm{a} \cdot \mathrm{x}^{\mathrm{b}}$

where $a, b, c-$ the regression coefficients.

The equations, with best statistical parameters (the highest correlation coefficient and lowest standard errors of estimation) were selected and tested with primary growth samples from the two other years.

The NIRS analysis was carried out on an InfraAlyzer $450($ Bran + Luebbe $\mathrm{GmbH}$, Norderstedt, Germany). The calibration equations for predicting the same tested parameters were obtained by multiple linear regression, separately for samples from primary growth and regrowth and for a combined group, including both growth samples from 3 different years. Two-thirds of the samples from the combined group were used as a calibration set and one-third as a validation set.

\section{RESULTS AND DISCUSSION}

The mean values and range of the CP and CF content, net energy (FUM, FUG, UFL, VEM) and protein value (PDI) for the samples from different years are shown in Table 1. The range of chemical composition, nutritive value and dynamic of growth of lucerne samples are similar to these reported by Paris et al. (1969), Ocokoljič et al. (1977) and Demarquilly (1981) for the lucerne growing in Mediterranean region.

The equations chosen on the basis of DV or AT, and the regression procedure results - correlation coefficient (r), standard error of estimation (SEE) and standard error of prediction (SEP) are shown in Tables 2 and 3. For CP content best results were obtained for linear equation $\mathrm{Y}=\mathrm{a}+\mathrm{b} . \mathrm{x}$, and for $\mathrm{CF}$ content - for quadratic equations $Y=a+b \cdot x+c \cdot x^{2}$ with both independent factors $D V$ and AT. Multiplicative equations $\mathrm{Y}=\mathrm{a} \cdot \mathrm{x}^{\mathrm{b}}$ best described FUM, FUG, UFL, 
TABLE ।

Mean values and range of the tested parameters for the primary growth and regrowth samples (in $1 \mathrm{~kg}$ dry matter)

\begin{tabular}{lcccc}
\hline Item * & \multicolumn{2}{c}{$\begin{array}{c}\text { Primary growth }(\mathrm{n}=31) \\
\text { range }\end{array}$} & $\begin{array}{c}\text { Regrowth }(\mathrm{n}=30) \\
\text { average }\end{array}$ & range \\
\hline $\mathrm{CP}, \mathrm{g}$ & $155-308$ & 227 & $132-259$ & 190 \\
$\mathrm{CF}, \mathrm{g}$ & $163-326$ & 260 & $183-373$ & 276 \\
FUM & $0.72-1.07$ & 0.866 & $0.69-1.07$ & 0.914 \\
FUG & $0.65-1.09$ & 0.834 & $0.62-1.09$ & 0.894 \\
UFL & $0.61-0.96$ & 0.740 & $0.61-0.98$ & 0.810 \\
VEM & $651-1002$ & 783.1 & $602-893$ & 775.6 \\
PDI, g & $78-121^{\circ}$ & 96 & $74-126$ & 94 \\
\hline
\end{tabular}

${ }^{*} \mathrm{CP}$ - crude protein

CF - crude fibre

FUM - Bulgarian feed units for milk

FUG - Bulgarian feed units for growth

UFL - French feed units for milk

VEM - Dutch feed units for milk

PDI - protcin, digestible in the small intestine according to the French system

TABLE 2

Regression equations on the basis of AT $(x)$ and statistical results for estimation of tested parametcrs (Y) for primary growth samples

\begin{tabular}{llccc}
\hline Itcm $^{*}$ & Equations & $\mathrm{r}^{* *}$ & $\begin{array}{c}\text { SEE } \\
\mathrm{n}=12\end{array}$ & $\begin{array}{c}\text { SEP** } \\
\mathrm{n}=8\end{array}$ \\
\hline $\mathrm{CP}$ & $\mathrm{Y}=336.74-0.16 . \mathrm{x}$ & 0.99 & 9.20 & 7.99 \\
$\mathrm{CF}$ & $\mathrm{Y}=991.71+0.321 . \mathrm{x}-0.00011 . \mathrm{x}^{2}$ & 0.99 & 5.62 & 12.98 \\
FUM & $\mathrm{Y}=3.299 . \mathrm{x}^{-0.214}$ & 0.97 & 0.022 & 0.045 \\
FUG & $\mathrm{Y}=4.872 . \mathrm{x}^{-0.282}$ & 0.98 & 0.024 & 0.055 \\
UFL & $\mathrm{Y}=2.056 . \mathrm{x}^{-0.171}$ & 0.92 & 0.026 & 0.034 \\
VEM & $\mathrm{Y}=2360.2 . \mathrm{x}^{-0.181}$ & 0.96 & 21.38 & 32.08 \\
PDI & $\mathrm{Y}=334.177 . \mathrm{x}^{-0.21}$ & 0.97 & 2.34 & 5.51 \\
\hline
\end{tabular}

$*$ as in Table 1

** $\mathrm{I}$ - correlation coefficient, SEE - standard error of estimation,

SEP - standard error of prediction 
TABLE 3

Regression equations on the basis of DV (x) and statistical results for estimation of tested parameters (Y) for primary growth samples

\begin{tabular}{llccc}
\hline Item & Equations & $\mathrm{r}^{* *}$ & $\begin{array}{c}\text { SEE** } \\
\mathrm{n}=12\end{array}$ & $\begin{array}{c}\text { SEP** } \\
\mathrm{n}=8\end{array}$ \\
\hline $\mathrm{CP}$ & $\mathrm{Y}=349.64-2.46 . \mathrm{x}$ & 0.99 & 8.41 & 12.94 \\
$\mathrm{CF}$ & $\mathrm{Y}=91.68+4.415 . \mathrm{x}-0.019 . \mathrm{x}^{2}$ & 0.99 & 5.47 & 8.29 \\
FUM & $\mathrm{Y}=2.061 . \mathrm{x}^{-0.237}$ & 0.97 & 0.023 & 0.030 \\
FUG & $\mathrm{Y}=2.623 . \mathrm{x}^{-0.313}$ & 0.98 & 0.024 & 0.036 \\
UFL & $\mathrm{Y}=1.415 . \mathrm{x}^{-0.189}$ & 0.92 & 0.026 & 0.036 \\
VEM & $\mathrm{Y}=1582.52 . \mathrm{x}^{-0.20}$ & 0.96 & 21.61 & 27.35 \\
PDI & $\mathrm{Y}=215.595 . \mathrm{x}^{-0.221}$ & 0.97 & 2.39 & 4.65 \\
\hline
\end{tabular}

* and ** - as in Table 2

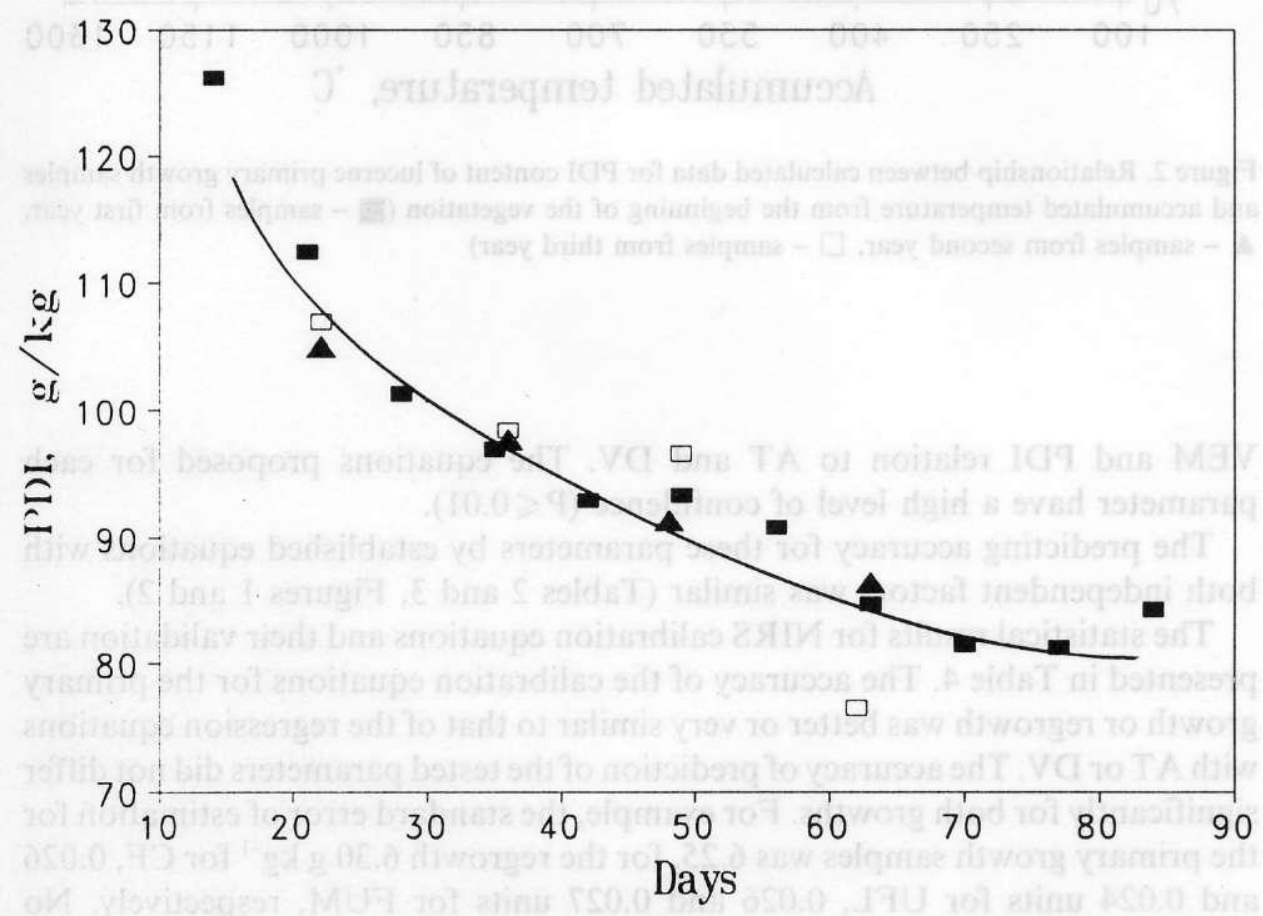

Figure 1. Relationship between calculated data for PDI content of lucerne primary growth samples and days from the beginning of the vegetation ( - samples from first year, $\boldsymbol{\Lambda}$-samples from second year, $\square$ - samples from third year) 


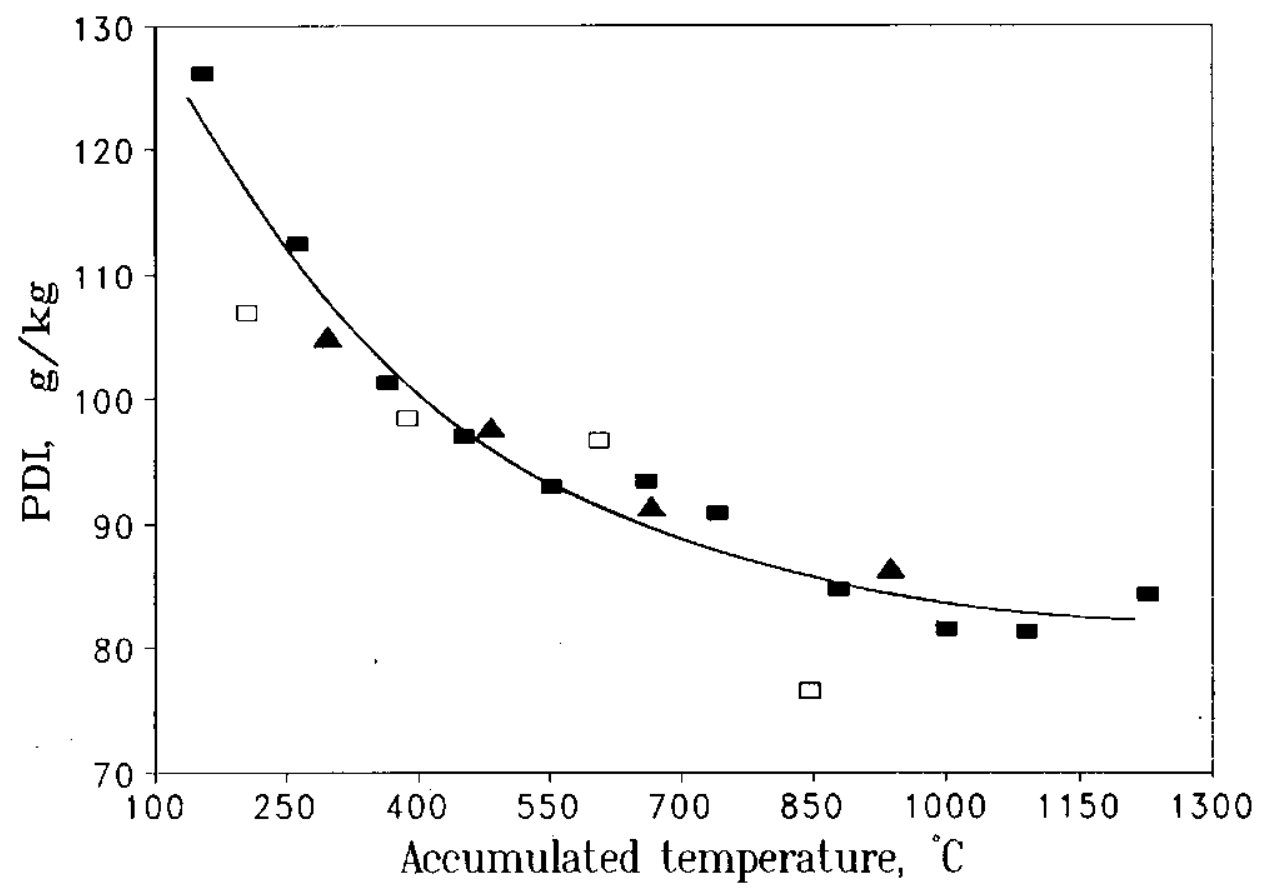

Figure 2. Relationship between calculated data for PDI content of lucerne primary growth samples and accumulated temperature from the beginning of the vegetation $(\square-$ samples from first year, $\Delta$ - samples from second year, $\square$-samples from third year)

VEM and PDI relation to AT and DV. The equations proposed for each parameter have a high level of confidence $(P \leqslant 0.01)$.

The predicting accuracy for these parameters by established equations with both independent factors was similar (Tables 2 and 3, Figures 1 and 2).

The statistical results for NIRS calibration equations and their validation are presented in Table 4. The accuracy of the calibration equations for the primary growth or regrowth was better or very similar to that of the regression equations with AT or DV. The accuracy of prediction of the tested parameters did not differ significantly for both growths. For example, the standard error of estimation for the primary growth samples was 6.25 , for the regrowth $6.30 \mathrm{~g} \mathrm{~kg}^{-1}$ for $\mathrm{CF}, 0.026$ and 0.024 units for UFL, 0.026 and 0.027 units for FUM, respectively. No significant differences in standard error of prediction were found for samples of the primary growth and the regrowth when they were analyzed by a general calibration equation including both growths (Table 4, Figures 3 and 4). 
TABLE 4

The statistical results for NIRS calibration equations and their validation

\begin{tabular}{|c|c|c|c|c|c|c|c|c|}
\hline \multirow[t]{2}{*}{ Item* } & \multicolumn{2}{|c|}{ Primary growth } & \multicolumn{2}{|c|}{ Regrowth } & \multirow[b]{2}{*}{$\mathrm{r}^{* *}$} & \multicolumn{3}{|c|}{ General equations } \\
\hline & $\mathrm{r}_{\mathrm{n}}^{* *}$ & $\begin{aligned} & \mathrm{SEE}^{* *} \\
= & 31\end{aligned}$ & $\mathrm{r}^{* *}$ & $\begin{aligned} & \mathrm{SEE}^{* *} \\
= & 30\end{aligned}$ & & $\begin{array}{l}\text { SEE** } \\
\mathrm{n}=43\end{array}$ & $\begin{array}{l}\mathrm{SEP}_{1} \\
\mathrm{n}=7\end{array}$ & $\begin{array}{l}\mathrm{SEP}_{2} \text { 蜡 } \\
\mathrm{n}=10\end{array}$ \\
\hline $\mathrm{CP}$ & 0.99 & 2.52 & 0.99 & 4.20 & 0.98 & 8.30 & 8.8 & 7.1 \\
\hline $\mathrm{CF}$ & 0.99 & 6.25 & 0.99 & 6.30 & 0.97 & 10.90 & 9.0 & 13.6 \\
\hline FUM & 0.98 & 0.025 & 0.97 & 0.027 & 0.96 & 0.029 & 0.026 & 0.029 \\
\hline FUG & 0.98 & 0.034 & 0.97 & 0.033 & 0.96 & 0.038 & 0.032 & 0.036 \\
\hline UFL & 0.97 & 0.026 & 0.97 & 0.024 & 0.94 & 0.029 & 0.029 & 0.024 \\
\hline VEM & 0.98 & 22.46 & 0.98 & 16.83 & 0.95 & 26.29 & 31.09 & 22.43 \\
\hline PDI & 0.99 & 1.71 & 0.99 & 2.08 & 0.98 & 2.21 & 1.86 & 1.46 \\
\hline
\end{tabular}

* and ** - as in Table 2

4 $-\mathrm{SEP}_{1}-$ standard error of prediction for the samples of primary growth

स $-\mathrm{SEP}_{2}-$ standard error of prediction for the regrowth samples

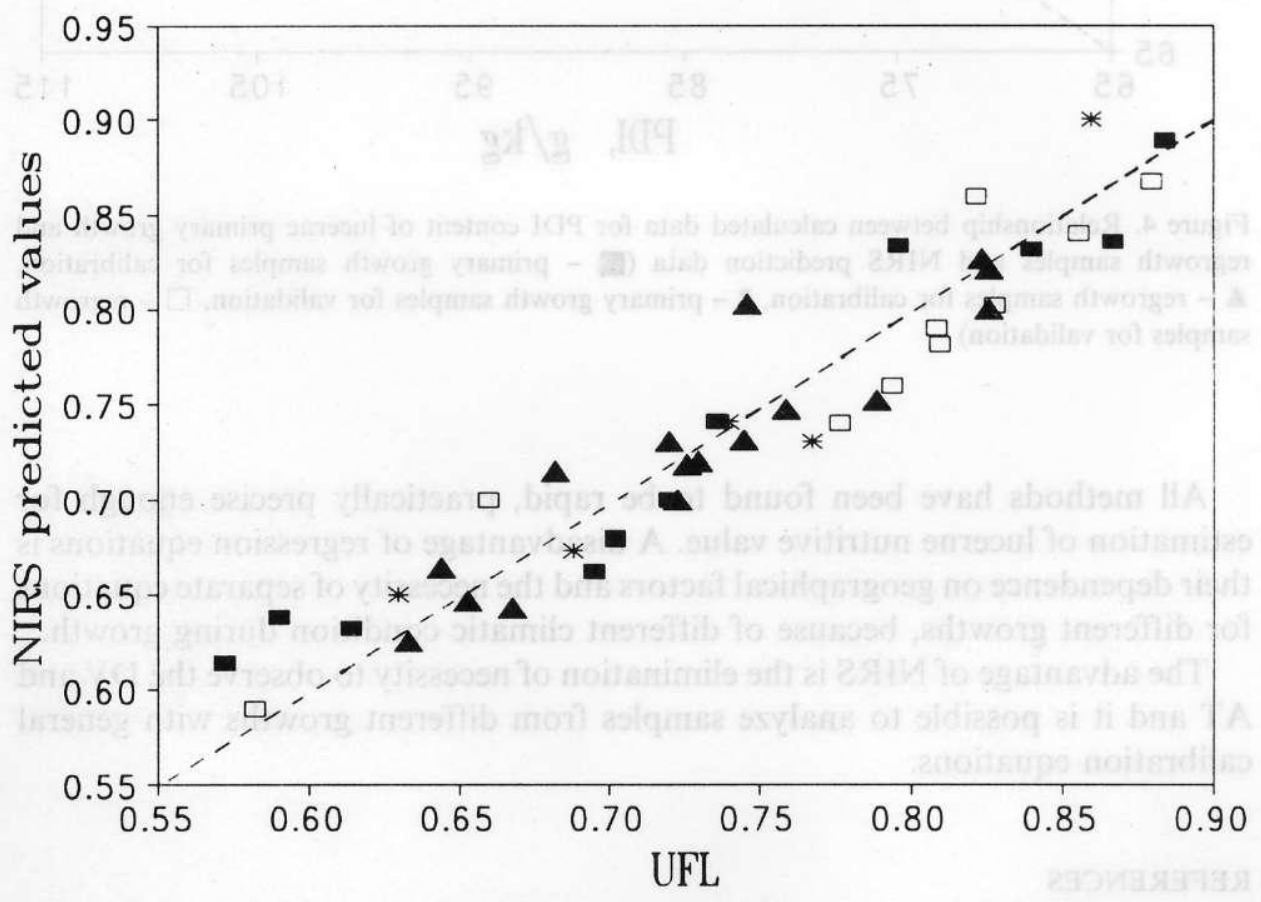

Figure 3. Relationship between calculated feed units for milk (UFL) of lucerne primary growth and regrowth samples and NIRS prediction data - primary growth samples for calibration, $\Delta$ - regrowth samples for calibration, ${ }^{*}$ - primary growth samples for validation, $\square$ - regrowth samples for validation) 


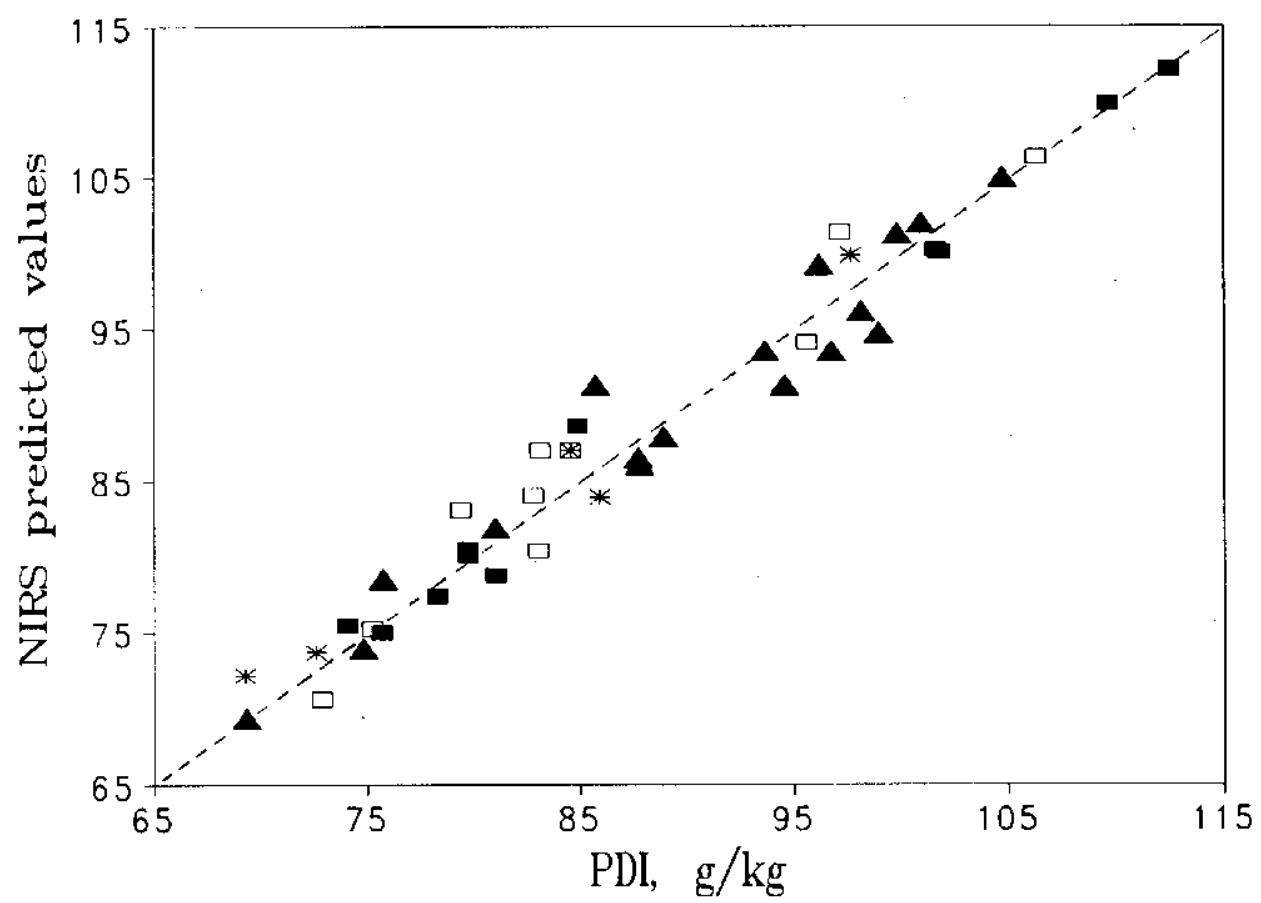

Figure 4. Relationship between calculated data for PDI content of lucerne primary growth and regrowth samples and NIRS prediction data ( $\square$ - primary growth samples for calibration, $\Delta$ - regrowth samples for calibration, ${ }^{*}$ - primary growth samples for validation, $\square$ - regrowth samples for validation)

All methods have been found to be rapid, practically precise enough for estimation of lucerne nutritive value. A disadvantage of regression equations is their dependence on geographical factors and the necessity of separate equations for different growths, because of different climatic condition during growth.

The advantage of NIRS is the elimination of necessity to observe the DV and AT and it is possible to analyze samples from different growths with general calibration equations.

\section{REFERENCES}

A.O.A.C., 1980. Official Methods of Analysis. 13th ed. Association of Official Analytical Chemists, Washington, DC, pp. 125-142

Brown W.F., Moore J.E., Kuncle W.E., Chambliss C.G., Porticr K.M., 1990. Forage testing using near infrared reflectance spectroscopy. J. Anim. Sci. 68, 1416-1427 
Demarquilly C., 1981. Prevision de la Valeur Nutritive des Aliments des Ruminants. INRA, Versailles, pp. 591

INRA, 1978. Alimentation des Ruminants. INRA Publications. Versailles, pp. 597

Jarrige R. (Editor), 1989. Ruminant Nutrition. Recommended Allowances and Feed Tables. INRA, Paris and John Libbey, London, pp. 389

Kalu B.A., Fick G.W., 1983. Morphological stage of development as a predictor of lucerne herbage quality. Crop Sci. 23, 1167-1172

Krasteva E., Todorov N., Marinov B., 1983. Handbook of Animal Nutrition (in Bulgarian). Zemizdat, Sofia, 37-47

Marten G.C., Brink G.E., Buxton D.R., Halgerson I.L., Hornstein I.S., 1984. Near infrared reflectance spectroscopy analysis of forage quality in four legume species. Crop Sci. 24, $1174-1182$

McDonald I., 1981. A revised model for the estimation of protein degradability in the rumen. J. Agric. Sci., Camb. 96, 251-252

Mehrez. A.Z., Ørskov F.R., 1977. A study of the artifical fibre bag tcchnique for determining the digestibility of feeds in the rumen. J. Agric. Sci., Camb. 88, 645-650

Minson D., 1990. Forages in Ruminants Nutrition. Acad. Press, San Diego, pp. 461

Naidenov T., 1988. Investigation and prediction of green and conserved forages (in Bulgarian). Thesis of Dr. Sci. dissertation. Research Institute of Fodder Production, Pleven, Bulgaria, pp. 251

Ocokoljič S., Paris Z., Velickovic G, Nicolic N., 1977. Effcct of the stage of plant development on crude protein, crude fibre and $\mathrm{N}$-free extract content in different vegctation cycles of alfalfa (in Serbian). Savremena Paljoprivreda, 3-4, 59-64

Paris Z., Ocokoljič S., Nicolič N. 1969. Studies in nutrient content and digestibility of organic matter of alfalfa in different phases of plant development (in Serbian). Savremena Poljoprivreda, 17, 979-984

Rubin B.A., 1976. Plant Physiology (in Russian). Kolos, Moscov, pp. 560

Shenk J.S., Westerhaus M.O., Hoover M.R., 1979. Analysis of forages by infrared reflectance spectroscopy. J. Dairy Sci. 62, 807-812

Todorov N.A., 1992. Feeding Standards for Cattle and Water Buffalo (on the basis of new energy and protein evaluation system) (in Bulgarian). Agricultural Academy, Solia, pp. 186

Van Fs A.J.H., 1978. Feed evaluation for ruminants. I. The system in use from May 1977 onwards in the Netherlands. Livest. Prod. Sci. 5, 331-343

\section{STRESZCZENIE}

Ornaczanie skladu chemicznego, energii netto $i$ wartości bialka lucerny przy zastosowaniu NIRS lub równań regresji $z$ uwzględnieniem dni wegetacji i temperatury

Oznaczono sklad chemiczny, energię netto i strawność w jelicie cienkim białka luccrny pierwszego i drugiego pokosu przy zastosowaniu NIRS lub równań regresji, uwzględniając dni i wzrastanie temperalury od początku wegetacji. Podano równania regresji określające przewidywaną wartość badanych wskaźników đla próbek lucerny z pierwszego pokosu w jednym roku uwzględniające dni wegetacji (DV) i narastającą temperaturę (AT) jako zmienne niezależne, i porównano je z wartościami otrzymanymi dla odpowiednich próbek $\mathrm{z}$ innych dwóch lat. Dokładność przewidywania wartości tych wskaźników z równań uwzględniających obydwa czynniki niczalcżne (DV i AT) byla podobna w poszczególnych latach i wystarczająca dla praktyki. 
Równania kalibracyjne dla metody NIRS dla pierwszego i drugiego pokosu wykazały lepsza, bądź bardzo zbieżną dokładność jak przy zastosowaniu równań regresji uwzględniających æmienne niezależne DV lub AT. Dokładność przewidywania tych wartości nie różniła się w sposób istotny między badanymi pokosami.

Standardowy błąd przewidywanych wartości dla próbek z pierwszego i drugiego pokosu nie byl statystycznie istotny, gdy był on wyliczany z ogólnego równania kalibracyjnego dla dwóch pokosów.

Zaletą metody NIRS jest to, że przy jej stosowaniu nie zachodzi potrzeba uwzględniania DV i AT i umożliwia analizowanie próbek $z$ różnych pokosów przy zastosowaniu ogólnej kalibracji. 